\title{
Interactive Storytelling through LEDs and Paper Circuits: Tapping into Materials and Technology in Children's Literature Education
}

\author{
Storytelling interactivo con LEDs y circuitos de papel: un \\ acercamiento a los materiales y la tecnología en la educación de la \\ literatura infantil
}

\author{
Storytelling interactiu amb LEDs i circuits de paper: un \\ acostament als materials i la tecnologia en l'educació de la \\ literatura infantil
}

Betül Gaye Dinç. University of Glasgow, UK. bdinc@ku.edu.tr https://orcid.org/0000-0002-7913-1382

Birce Özkan. Koç University, Turkey. ozkab856@newschool.edu https://orcid.org/0000-0002-6441-9498

IIgım Veryeri Alaca. Koç University, Turkey. ialaca@ku.edu.tr

https://orcid.org/0000-0002-7512-1507

\begin{abstract}
How can interactive technology enhance children's literature? How can new materials and technology be incorporated into courses on children's literature at university level feeding upon the Human-Computer Interaction (HCI)? What is the best way to embed new materials such as paper circuits into a children's narrative? This article offers a review of an experiment conducted at a liberal arts college where students were provided the theoretical and practice-based knowledge for designing children's picturebooks, then asked to introduce circuit technology to their picturebook design. The upper-level course admitted students from across a range of disciplines, such as computer science, psychology, literature, medicine, and media and visual arts, which resulted in lively exchanges between them. Regardless of their strengths, students participated in the hands-on workshop supported by a designer and the course instructor to learn about electric circuits, copper tape, and LEDs, and seek ways to adapt them into the page structure and the narrative sequence. They explored how to fuse light into text and image so as to tell a story and facilitate engagement in a children's book. This study builds upon the Maker Movement and borrows technology from HCI, fusing the two movements into children's books. As such, students were asked to assess the potential uses of HCI technology in art and design, book arts and seek ways to apply those technologies to enrich children's engagement during reading. Students revealed that this endeavour motivated them to think creatively as they explored ways to transform children's literature. Thus, the course brought theory and practice together with electric circuits to offer a novel way to contemplate children's literature.
\end{abstract}

Keywords: picturebook, paper circuits, technology, practice, theory 


\section{Resumen}

¿Cómo puede la tecnología interactiva mejorar la literatura infantil? ¿Cómo pueden ser incorporados nuevos materiales y tecnología en cursos de literatura infantil a nivel universitario alimentando la Interacción Humano-Ordenador (HCI)? ¿Cuál es la mejor manera de incorporar nuevos materiales como circuitos de papel en la narrativa infantil? Este artículo presenta la revisión de un experimento llevado a cabo en una facultad de artes liberales en la que se ofreció al alumnado el conocimiento teórico y práctico para diseñar álbumes ilustrados para la infancia y después se le pidió introducir tecnología de circuitos en el diseño de estos álbumes. El curso de nivel superior admitía estudiantes de un amplio abanico de disciplinas como informática, psicología, literatura, medicina y artes en medios de comunicación y artes visuales lo que supuso un dinámico intercambio en el grupo. Al margen de sus fortalezas, el estudiantado participó en el taller práctico con el apoyo de una persona diseñadora y la responsable del curso para aprender sobre circuitos eléctricos, cintas de cobre y LEDs y buscó maneras de adaptarlos a la estructura de la página y la secuencia narrativa.

El grupo exploró cómo fusionar luz con el texto y la imagen de forma que contara una historia y facilitara la participación en el libro infantil. Este estudio utiliza el Maker Movement y toma prestada tecnología del HCI, y hace converger los dos movimientos en libros infantiles. De esta manera, se pidió al alumnado evaluar los usos potenciales de la tecnología HCI en arte y diseño y libros de arte y buscó formas de aplicar estas tecnologías para enriquecer la motivación durante la lectura. El alumnado reveló que este esfuerzo le motivó para pensar creativamente mientras exploraban maneras de transformar literatura infantil. Así pues, el curso unió teoría y práctica junto con circuitos eléctricos para ofrecer una nueva manera de contemplar la literatura infantil.

Palabras clave: álbumes ilustrados, circuitos de papel, tecnología, teoría y práctica

\section{Resum}

Com pot la tecnologia interactiva millorar la literatura infantil? Com poden ser incorporats nous materials i tecnologia en cursos de literatura infantil a nivell universitari nodrint la Interacció HumàOrdinador (HCI)? Quina és la millor manera d'incorporar nous materials com circuits de paper en la narrativa infantil? Aquest article presenta la revisió d'un experiment dut a terme en una facultat d'arts liberals on es va proveir l'alumnat del coneixement teòric i pràctic per dissenyar àlbums il-lustrats per a infants i després es va demanar introduir tecnologia de circuits en el disseny d'aquests àlbums. El curs de nivell superior admetia estudiants d'un ampli ventall de disciplines com informàtica, psicologia, literatura, medicina i arts en mitjans de comunicació i arts visuals, la qual cosa va suposar animats intercanvis entre tothom. Sense tindre en compte les seues fortaleses, l'estudiantat va participar en el taller pràctic amb el suport d'una persona dissenyadora i la responsable del curs per aprendre sobre circuits elèctrics, cintes de coure i LEDs, i va buscar maneres d'adaptar-los a l'estructura de la pàgina i la seqüència narrativa.

El grup va explorar com fusionar llum dins del text i la imatge de manera que contara una història i facilitara la participació en el llibre infantil. Aquest estudi fa servir el Maker Movement i agafa prestada tecnologia de l'HCI, tot fent convergir els dos moviments en llibres infantils. D'aquesta manera, es va demanar a l'alumnat avaluar els usos potencials de la tecnologia HCI en art i disseny i llibres d'art i va buscar formes d'aplicar aquestes tecnologies per enriquir la motivació durant la lectura. L'alumnat va revelar que aquest esforç el va motivar per pensar creativament mentre exploraven maneres per transformar literatura infantil. Així, el curs va unir teoria i pràctica juntament amb circuits elèctrics per oferir una nova manera de contemplar la literatura infantil.

Paraules clau: àlbum il·lustrat, circuits de paper, tecnologia, teoria i pràctica 


\section{Integrating Interactive Technologies into Children's Literature Education}

How can interactive technologies enhance children's literature? How can new materials and technology be included in courses on children's literature drawn from the vast field of Human Computer Interaction ( $\mathrm{HCl})$ ? How do innovations in Light Emitting Diodes (LED) and paper circuits revolutionize picturebook design and enrich the creative process? LEDs are also utilized in myriad other platforms and ties into the $\mathrm{HCl}$ world in remarkable ways. It is important to note that LED based research is an expanding topic in the field of $\mathrm{HCl}$, having been integrated into multiple diverse studies from wearables to sensor-based systems that reveals the layered utilization and adaptability (see LED related research in ACM Digital Library 2021). $\mathrm{HCl}$ all by itself is a vast and an ever-growing field that many disciplines and technologies call into play from graphics, multimedia technologies and education to communication systems. The interactions that come forth with LEDs can be studied through the lens of interactivity and could be linked to our case study as well.

According to Svanaes (2014), interactivity has been often defined from two approaches, objectcentred as the object's affordances in response to the user's actions and Unser-centered focusing on the user's needs and ways of engaging with these objects' features. In $\mathrm{HCl}$, interactivity encapsulates a wide range of computing systems and materialities from myriad digital engagements, games, robots, Artificial Intelligence (Al) to mundane objects enhanced with electronics (e.g., conductive materials). Panjwani (2017) defines daily physical objects enhanced with electronics as tangible computational media stating"the tools that allow us to create physical objects that have computational capabilities, enabling us to construct new interactions and behaviors" (p. 358). For example, paper is one of these materials that researchers and designers in $\mathrm{HCl}$ often revisit to create tangible interactions with conductive systems, as LED lights, tested out for storytelling with children (Jacoby \& Buechley, 2013, p. 265; Qi et al., 2015, p. 438; Panjwani, 2017, p. 359). Our work aims to shed light on these innovative steps and introduce them to our children's literature course.

This study was conducted at a liberal arts college, Koç University, during the spring term in 2019 and explores the role of paper circuit technology as a case study in an upper-level elective course on children's literature open to undergraduate and graduate students from diverse disciplines. Since this fifteen-week course was not mandatory and open for enrollment to diverse body of students, the 27 students who signed up majored in a variety of subjects such as media and visual arts, psychology, computer science, literature, medicine, and art history at undergraduate, MA, and PhD levels. Regardless of their diverse career paths and trajectories, all 
students shared an interest in children's books and tried to find ways to integrate this technology into their creative projects for this course.

Our case study draws attention to the vast possibilities that may open up when disparate fields such as $\mathrm{HCl}$ and children's literature studies come together and develop new research pathways. Integrating LEDs, paper circuits, and tiny light bulbs into picturebooks strays into the territory of $\mathrm{HCl}$ design. Merging theory and practice, the circuitry workshop component of the 'Children's Books' course emerged from initial exchanges between a guest instructor, Birce Ozkan, a designer and fashion technologist, and the instructor, Ilgım Veryeri Alaca. The concept of this workshop evolved further as the instructor, designer, and the research assistant, Betül Gaye Dinç developed ideas based on related research and integrated these into the process. From its inception, this collaboration that created a dialogue among different stakeholders from the university and the design world was founded on the premise that collaboration could and would enhance learning. In this respect, this study indicates that courses that draw from diverse disciplines to explore the innovations for interactive picturebooks connect different parties in one conversation.

During the Children's Books course, a cross-section of children's literature is presented to tap into topics such as emergent literacy, image and text

In this respect, this study indicates that courses that draw from diverse disciplines to explore the innovations for interactive picturebooks connect different parties in one conversation relationships, and trends in contemporary picturebooks. This approach to instruction grants students a working knowledge of the various approaches and theories in this field while the workshop explains the basics of producing a picturebook, the overall relation between practice and theory, and finally explores the potential of technologies to enhance production. Together, the course lays out picturebook design and illustration involving practice that employs conventional and contemporary illustration methods which students can draw upon to create interactive children's books. Similar to other children's literature related classes taught at various liberal arts colleges and education departments (Salisbury \& Styles, 2012; Mathis et al., 2014), fusing practice and research in narrative illustrations and picturebooks constitutes the backbone of this course.

In their discussion on New Materialist approaches in teaching, García-González and DeszczTryhubczak (2020) consider the concerns of university students in arts-driven courses, such as making children's books, that involving theory might blunt their creativity. There are some 
students who are not versed in art theory or literature and yet they seek to engage with the creative side of children's books. Whether coming from a field of purely practical experience or with no background knowledge about the topic, students in this Children's Book course need instructors to help them explore comprehensive and insightful methodologies that will captivate their interest and skillfully combine practice with theory. Despite some concerns, theory has been shown to support and enrich practice and accommodate the creative process in drawing and illustrating (Veryeri Alaca \& Onmus 2018; Veryeri Alaca \& Dinç, 2019). In the field of children's picturebooks, theory as valuable to ensuring students are knowledgeable about the process. Salisbury and Styles (2012) explain that "new knowledge about the process and practice of making picturebooks, to add to what is already known about a completed artefact and the ways in which it can be read" (p. 54) round out the creation of a picturebook. Therefore, practice-based exercises supports grasping research in picturebook studies, especially when combined with tacit knowledge built by the students themselves. The practical and theory-based involvement with children's literature help to make sense of the narrative, design, material as well as overall production choices of books.

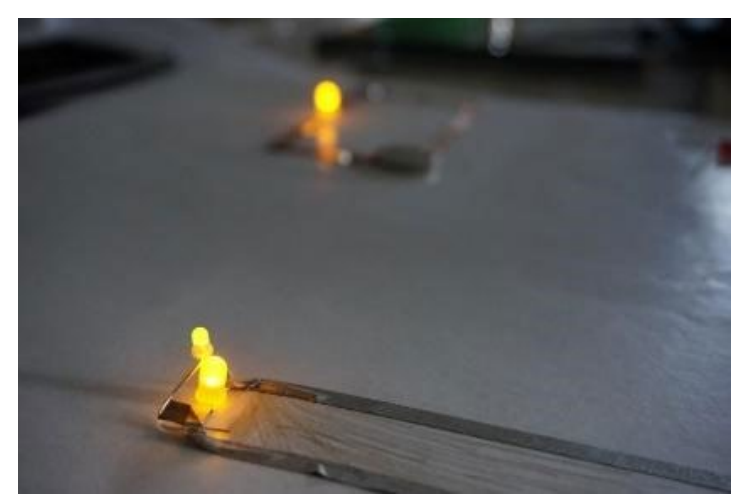

Figure 1. Photo from the course, by Ilgım Veryeri Alaca, 2019

Picturebooks are multimodal in that they offer various graphic devices, both text and images, and physical features that students can employ and incorporate into their creative process. The multimodality is often closely aligned with the current technology. Making meaning through picturebooks is not reliant on only one mode (either text or image), but rather draws from at least two different sources (such as image, and text). In connection, even as linguistic, visual, audio, gestural, and spatial features are interwoven together in a multimodal literacy object (Cope \& Kalantzis, 2000), new materials incorporated into picturebooks can play significant roles in children's experiences. 
Special features such as light effects, pop-ups, and games have been utilized in children's literature throughout the ages. Traditional children's books would perforate the page with embedded imagery, filigrees that could only be observed when held up to light, revealing its secret content to its child audience (Bromer Anne \& Edison, 2007; Veryeri Alaca, 2018). While this feature is not technologically advanced, it is a precursor to contemporary examples interwoven with light filigrees that can be activated by various means. Mona Leu-leu's Le Grenier (2017), for instance, makes use of a magic flashlight that illuminates the images hidden in the grey illustrations, spotlighting their shadowy forms. The act of shining a light on the pages of the book to tell the story is also utilized in Hervé Tullet's board-book entitled The Game of Shadows (2013). Here, however, the cut-outs in the pages of the book cast silhouettes of animals and people on the wall of a darkened room. Emerging research on the uses of light and reading has found it could be beneficial in special cases such as teaching sign language through shadow play (Ceylan, 2019).

Paper, conductive copper tape, LEDs, and a power source such as a cell battery constitute "paper electronics" (Qi et al., 2015, p. 440) or "paper circuitry" (Shorter et al., 2014, p. 40) (Figure 1) that can be utilized in different educational platforms. As far as creating basic circuitry for the course's workshop was concerned, we chose materials and components that are accessible, useful, and affordable for students. Following the "paper electronics" examples, we used paper, strips of conductive tape, LEDs, and a coin cell to power the circuit. We chose to use paper not only because it is commonly used in children's books but because of its malleability that makes it possible for the students to bend it to fit their creative and expressive narrative work. Through these materials, this course blends the two disciplines of $\mathrm{HCl}$ and children's literature, and employs perspectives from education, art, and design.

In this study, we first introduce the multimodal utilizations of circuitry and its potential applications for interactive picturebooks. Second, we unpack the circuitry workshop carried out in a children's books course at university level and then ask undergraduate and graduate students to discuss their first impressions of what 'interactivity' in picturebooks might signify. Third, we focus on students' responses to the questionnaire and the worksheet where they record their picturebook engagements triggered by LEDs through sketches. Last, we present and discuss selected final projects from the workshop, which offer us insights into developing teaching methodologies and curriculums for courses on children's books at the higher education level. 
In sum, to remain relevant in an increasingly digital world, the narrative and material affordances, necessary components of a traditional book, of picturebooks have become progressively more interactive. The purpose of our workshop's sessions on the selected technologies was to provide university students with an array of perspectives on the instrumentalization of these new materials in picturebooks. As one of the aims of our children's books course is to introduce material aspects of picturebook making to university students, it was beneficial for our class to engage with the maker movement through learning examples of interactive The purpose of our workshop's sessions on the selected technologies was to provide university students with an array of perspectives on the instrumentalization of these new materials in picturebooks. garments, artworks, besides picturebooks that will be discussed in the next section.

\section{Paper Circuitry, Interactive Picturebooks, and Maker Movement}

While some upper-level courses on children's literature do involve creative writing and illustration, those that include a focus on the material aspect of books support the exploration of different approaches to make meaning out of the existing story. Materiality that may be regarded as "a third narrative" in a story, after the text and images, encourages children to explore book textures, manipulate the structure, and comprehend the narrative through varied interactions (Veryeri Alaca, 2018, pp. 62-63). Interactivity in children's print books is based on physical (e.g., from touching to pushing buttons and redesigning the book) and narrative (e.g., from linear to nonlinear, puzzles or games) engagements (Timpany \& Vanderschantz, 2012).

Materiality and interactivity, in addition to their relevance in the expanding field of children's literature, are also significant in the $\mathrm{HCl}$ community and maker culture. The Maker Movement sprung up around the publication of Make magazine and supported through Maker Faire, an annual event where do-it-yourself adherents are invited to exhibit their creations (Dougherty, 2012; Honey \& Kanter, 2013). The idea of this magazine and event is to circulate knowledge and encourage people to invent their own devices or products through low (e.g., conventional crafting) or high technology (e.g., digital interactions) rather than engage in wide-scale consumption (Dougherty, 2012). Making is not merely about technology but about combining technology with art, culture, and education by incorporating everyday materials, such as papers, doughs, and textiles with circuits.

The soft circuit technique that employs traditional craft materials and basic technological tools is just one way to create technological interactions with daily objects (Cheng et al., 2012). 
Textiles are often a popular choice for the maker community both for their versatility and for their visibility as wearable computing. Fashion designer Hussein Chalayan is among those who have integrated circuits into his designs, and in 2007 (Design Museum, n.d.) his innovations were recognised as his $L E D$ dress that glows in the dark won him the Brit Insurance Designs of the Year Award. Ozkan (2015), the designer involved in this study, also produces interactive garments inspired by nature's responsiveness. Ozkan's interactive design Fall (2015) is a dress equipped with sensors that detect temperature as well as light levels, and when light is low, the dress is programmed to shed leaves mimicking trees in autumn (Ozkan, 2015). These interactive and sensorial experiences via e-textile translate into reading as well. Moorthy et al. (2017) embedded sounds and LED lights into a textile-based book to enhance the traditional touchand-feel books by computerizing the textiles to enhance young children's engagement and interaction. Children may pull the fish's tail to play a tune, press on a bear's furry belly to activate vibration, or turn on and off LED lights to guide a firefly.

Just as copper tape or various conductive inks (e.g., silver or thermochromic ink) can create circuits to convey energy and transform textiles and threads, so can paper be transformed. With an Arduino board and conductive paint, paper can turn into a piano (De La Cruz \& Bhatia, 2018); with conductive ink, epoxy, and laser cutting, cardboard can transform into a set of headphones (Shorter et al., 2014). Cheng et al. (2012) use an origami herringbone tessellation to create an interactive light that can be altered by manipulating, squeezing, or stretching out its shape to create new patterns of light. Even the colours printed on a page can be altered by touch with the help of thermochromic ink that senses the changes in temperature on the page (Tsujii et al., 2014). For example, Sofia Aronov's art piece, Awake (2018), was not created with a projector; rather it was painted on a canvas with electronic ink and every time the viewer touches the ink, different images appear (Bareconductive, 2021). These technologies challenge artists to experiment with paper crafting to find creative and aesthetic ways to present everyday objects in a manner that will spark the viewers' imaginations.
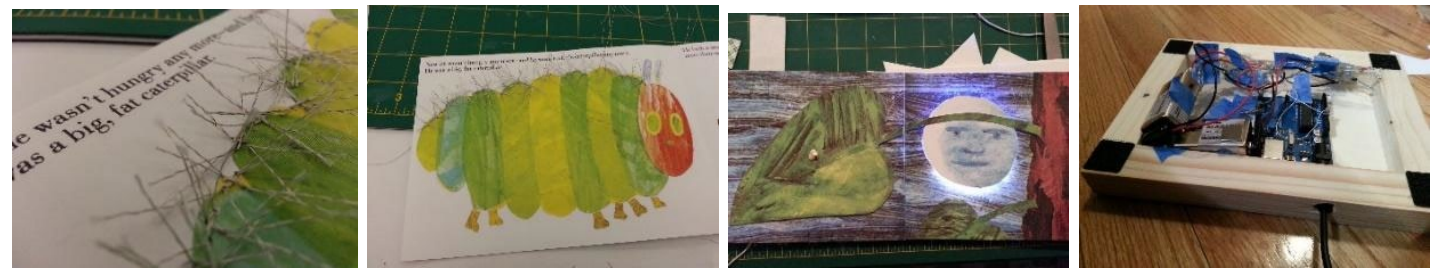

Figure 2. The Very Hungry Caterpillar [Interactive] (2013), by Jeannette Subero ${ }^{1}$

\footnotetext{
${ }^{1}$ Figure 2a. conductive threads that react to touch, detail. Figure $2 b$. conductive threads that react to touch, detail. Figure 2c. glowing moon due to embedded circuits. Figure $2 \mathrm{~d}$. electronic mechanism that supports various interactions such as the butterfly moving its wings on the final page.
} 
The creativity of designers and artists organically extends to encompass books. The designer Jeannette Subero (2013) transformed Eric Carle's famous interactive book, The Very Hungry Caterpillar (Figure 2), into a more sensorial reading activity. If the reader touches the surface of the leaves, the moon shines (Subero, 2013, 00:10), or if she strokes the caterpillar's cocoon, the conductive threads activate thermochromic ink, and as a result the colour changes and reveals a message (Subero, 2013, 01:41). When she traces the path of the butterfly with her finger, the butterfly flutters its wings (Subero, 2013, 01:56). She introduces new materials and technologies to push past the limitations of the traditional touch-and-feel books and activate children's senses by handling objects and textures.

Electronics designer and artist Jie Qi (2010) combined her skills in an interactive pop-up book that with the turn of each page offers new interactions with the 3D shapes lit up with LEDs. In an underwater scene, jellyfish can be moved horizontally across the page or lit up by pressing a tab (p. 124). In a garden scene of Venus flytraps, putting one's finger inside the flower's maw activates the sensors to snap the flower closed on the finger (pp. 126-127). Her artworks fuse paper and circuitry in creative explorations reminiscent of the do-it-yourself movement. Qi et al. (2015) have also designed Chibitronics circuit stickers that blend LED and conductive tape to build circuits without the hazards of the conventional circuit tool kits (p. 439). ${ }^{2}$ Based on Chibitronics, Qi (2015) created a Circuit Sticker Sketchbook to teach children about electronics (p. 440). By following the instructions in the book, children can create simple and more complex circuits, implement coin cells with button or slide switches and pressure sensors that come together to activate the LED lights (p. 440). They learn how to merge the paper's materiality with the electronics that they can then apply the knowledge gained to new media in more playful and creative ways which reflect their personalities or talents with new media.

Kim and Zimmerman (2017) assert that engaging with conductive materials (e.g., conductive dough/squishy circuits) encourages children to role-play, make aesthetic decisions, collaborate with peers, and experiment with technology (trial-and-error) (Kim \& Zimmerman, 2017). Similarly, Panjwani (2017) conducts a workshop on conductive materials, such as paper electronics, e-textiles, and programmable projection on three-dimensional paper sculptures. In this workshop, children create interactive narratives to tell the story of their personal experiences and everyday lives by melding together different materials that complement their narration (Panjwani, 2017). When conductive materials meet narratives, makers are expected

\footnotetext{
${ }^{2}$ According to Qi (2015), Chibitronics are conductive stickers, mainly for light, and developed as a toolkit to teach paper circuitry.
} 
to adopt materials, visuals, and texts to create a complete story. While drawing with conductive ink or other art supplies, children can use them for artistic or practical purposes. Another facet

When conductive materials meet narratives, makers are expected to adopt materials, visuals, and texts to create a complete story. While drawing with conductive ink or other art supplies, children can use them for artistic or practical purposes. of creating is implementing voice recorders allowing the characters to voice the text in the speech bubbles or makes the panels of the storyboards speak (Jacoby \& Buechley, 2013). Conductive materials prompt children to question the selected elements in drawings while electronic recorders help them to cope with the literary elements in a story. Therefore, circuits offer the freedom to explore imaginary worlds but still guide young children as caregivers read to them until they develop into independent readers.

Fusing circuits into the narration and aesthetics of children's books signify the role of novel and emerging toolkits for university students to tap into contemporary children's literature. Considering that our upper-level course specialises in numerous aspects of children's literature, the students that sign up already have a close bond with this field which they seek to advance. For instance, some of our students were graduate students of Psychology, who wanted to incorporate children's books into their ongoing work and two were already studying for their masters in relation to children's literature. Hence, our case study with circuits was addressed to those who could potentially incorporate this knowledge and experience into their field work. Although there are studies on teaching programming skills to liberal arts students at university level via computing and interactive multimedia (Andersen et al., 2003), teaching paper electronics at the university context in a children's books course has a more focused target and outcome. Qi and Buechley (2014) conducted several paper-circuit workshops with undergraduate and graduate students majoring in different fields (art, graphic design, industrial design, science, architecture, and engineering etc.) and working adults with a focus on participants' responses to the technology. They found that while some of the participants only created circuits with a focus on the technology, others created paper circuits with conceptual or artistic aspects according to their interests. However, in these examples, the potential impact of paper circuitry on children's education or picturebook creation are not considered whereas our students explored specific ways to bridge circuits to contemporary children's literature studies. Incorporating the multiple applications of these new materials into children's education would benefit from the craft-oriented aspects of the maker culture. Not only does the Maker Movement suggest ways to combine every-day materials and materialities children are familiar 
with, incorporating electronics also it guides us to think beyond teaching technology as if it were detached from the rest of life. The results of this study can be expanded with additional exercises for further integrations of technology into the university curriculum with specialization in picturebooks or children's literature. Our students were given the chance to familiarise themselves with the potential transformations in children's literature thus gaining insights into the impact diverse disciplines have on this field.

\section{The Circuitry Workshop}

As a component of the Children's Books course, the Circuit Making workshop aimed to introduce conductive materials to the participants Before that, the course commenced with an overview of selected studies on children's literature followed by an analysis of selected books to provide the background information necessary for the practical part of the second half of the semester. Once the workshop was underway, students had already familiarised themselves with global and local contemporary examples of picturebooks and with their subject through readings such as How Picturebooks Work (Nikolajeva \& Scott, 2006), Illustrating Children's Books: Creating Pictures for Publication (Salisbury, 2004), Emergent Literacy: Children's Books from 0 to 3 (Kümmerling-Meibauer, 2011), Keywords of Children's Literature (Nel \& Paul, 2011), Reading Visual Narratives: Image Analysis of Children's Picture Books (Painter, Martin \& Unsworth, 2013), and The Routledge Companion to Picturebooks (Kümmerling-Meibauer, 2018). These readings primarily provided insight into the engagement of visual, verbal, and material narratives in picturebooks and the effects on children's reading. To round off this knowledge, students also consulted on-site library sources as well as online digital resources to enrich their understanding of children's literature through additional readings that had been recommended. Putting theory into practice, the primary objective of the workshop was to encourage students to consider new technology and how it may be utilized in children's books, then experiment with basic circuit and conductive materials so as to create interactive narratives. To achieve this goal, the workshop was divided into three sections: the introductory session with presentations, the experimental session, and a final session to critically review the finished projects. During the experimental session, students spent time brainstorming, sketching ideas, and then rendering those ideas into a book format that included circuits either physically or hypothetically throughout the book or in certain strategic places. Thus, these tasks encouraged them to combine writing, drawing, and making to create an interactive picturebook.

Practice-based and practice-led research indicates that writing through a significant tool can be challenging for students. In 2007, in a workshop organized by Sheffield Hallam University, 
researchers, designers, and artists from diverse fields (e.g., picturebook illustrations, architecture) discussed art education in practice-led research (Rust, Mottram \& Till, 2007). One of the

As a children's book course outcomes of this workshop was artists' struggle to document the research process in writing when crafting, making, illustrating, or drawing was their preferred way of communicating (Rust, Mottram \& Till, 2007). As a children's book course that had an interdisciplinary audience, we endeavoured to create an environment that that had an interdisciplinary audience, we endeavoured to create an environment that fostered exchange between those students who were comfortable with writing and those comfortable with making fostered exchange between those students who were comfortable with writing and those comfortable with making. Before starting the hands-on portion of the workshop, students first received a combination questionnaire worksheet where open-ended questions guided them in an unstructured manner to cogitate on the picturebooktechnology relationship. Space was provided to take notes or illustrate their ideas in terms of finding alternatives ways to integrate technology into their storytelling. These worksheets were submitted with the final projects that gave students time to continue taking notes and document their responses during the creative process. As students also wrote ideas about their project and drew their initial sketches, these sheets played the role of a mini sketchbook as well.

The answers to these questions revealed how students, without requiring knowledge on the Maker Movement or on $\mathrm{HCl}$, perceived technology, electronics, wearables, textiles, and crafts. Some words that students used to describe technology included "catchy", "popular", "practical", "available" and "familiar to children". Most of the students viewed technology in children's daily lives with some concern, while others mentioned the advantages of technology in children's learning based on play and agency. For example, according to B. Ö., "the learning process becomes fun and interesting for children when text and technology are combined". C. K., however, believes that "the most important benefit of technology for children's education is that it made a lot of learning and teaching materials accessible without needing help from professional teachers and tutors".students' answers revealed that the first thought to come to mind when asked about the relationship between technology and children's book was iPads or e-books, followed by interactive books embedding sounds and physical engagements. When asked to state their views on the role technology plays in non-digital books, E. Ş. B. pointed out "I think that technological materials lead to a more interactive (animal sounds, numbers, singing books, etc.) reading for children as they can move/turn on something and can see the reaction in a second". I. E. cited benefits to the image-text-material relationship, explaining that 
"technology provides the link between words and meanings for children. For example, books that aim to teach about animals. When you see a cow on a page supported via a button and you can hear the sound a cow makes. MOO!". While participants considered their answers to the questions about technology and children's books, the space left in these worksheets invited students to think on, sketch out and plan the role of the circuits' affordances in their story.

Smaller assignments laying the foundation for the main project were designed to encourage students to think about how they would use LEDs, circuits, and connectivity and whether to conceal or leave the circuits exposed. Shorter et al. argue (2014) that "paper circuitry is honest; there are no computers hidden under tables, or projectors behind doors. Everything is physically included in the prototype, and paper circuits shy away from unnecessary complexity and expense" (p. 40). During the workshop, students started to discuss how image, text, and sensorial interactions are combined in existing interactive books and how they would integrate them into their book designs. Some of the students favoured transparency and considered how visible paper circuits could be used to develop children's understanding of technology, whereas others preferred to conceal the circuits so the effect would come as a surprise. Yet, others employed paper circuits to accentuate objects or complement the narrative: LEDs for eyes and stars, the circuit paths for the roads or flows, and connectivity for a meeting after a long time.

Previous discussions on how they might enhance existing picturebooks through technology were another valuable resource. Students were asked to modify the scene from Hiawyn Oram and Satoshi Kitamura's Angry Arthur (1982, pp. 3-4) that depicts the release of Arthur's anger as a nimbus of yellow, the zigzagging rays of an explosive flash, and tossed-aside furniture (Doonan, 1991, p. 113). Some suggestions included the addition of sounds such as the crack of lightning, light to highlight the explosive flash, vibration at the moment of cracking, and furniture pieces that can be moved to amplify the dramatic effect of the selected image. Pondering the revision of an existing scene employing various technological features and affordances encouraged some students to work on adaptations of existing children's literature. The exercises in conjunction with the readings laid the foundation for exploring further the potential of using circuitries in storytelling.

\section{Hands-on Experiments for Interactive Engagements}

As mentioned above, the first part of the workshop was dedicated to presenting related artworks of different designers, crafters, and technologists and then introducing students to soft circuits and paper-based engineering techniques from origami to pop-ups. After this presentation, Ozkan explained paper circuits and basic circuit making as a first step to 
understanding how electronics work. She projected a diagram of the basic circuit and suggested students sketch it before gathering a coin cell battery, a LED light, and copper tape (Figure 3). After observing the demonstration, the students successfully added the copper tape, LED light, and battery to their diagram to make their first simple light-up circuit. This was followed by an activity where students sketched ideas for interactive narratives in their questionnaire worksheets and started to experiment with the materials.

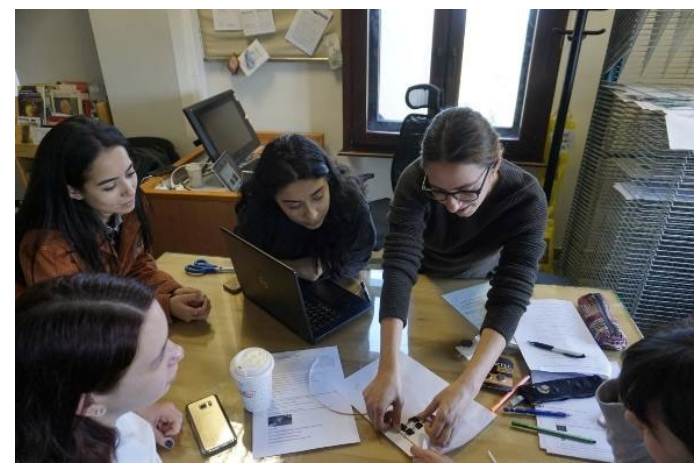

Figure 3. Photo from the course, by Ilgim Veryeri Alaca, $2019^{3}$

While some of the students collaborated on creating circuits, others preferred to work independently. Some of the students started to manipulate the paper to create interactive narrative scenes such as glowing traffic lights or origami pieces such as a lighting paper boat. The student T. C. drew King Arthur wielding his sword and arced copper tapes around the figure to denote a halo of light and the sword's might (Figure 4). The addition of LED lights in a variety of colours from yellow to green to red strengthens the dramatic moment of the tale.

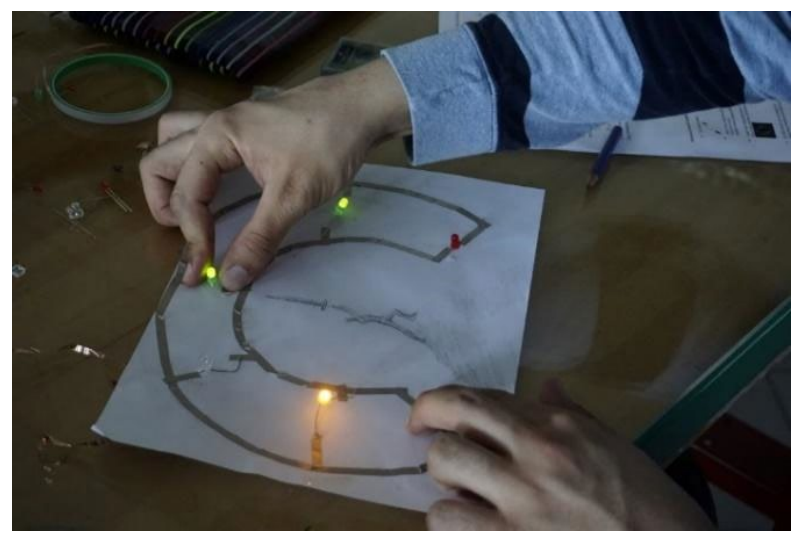

Figure 4. Photo from the course, by Ilgım Veryeri Alaca, 2019

Just as mastering technological literacy offers ideas for visual arts (Stankiewicz, 2003), drawing sketches and making drafts are significant steps in the process of designing products or

\footnotetext{
${ }^{3}$ Note. All pictures reproduced with permission.
} 
interactions. Salisbury and Styles (2012) assert that keeping a sketchbook to record impressions that can later be transformed into a tangible medium is important for any artist as it contributes to developing a unique style (p. 58). Difficult or not, sketches were necessary for this workshop to record initial ideas and chart the evolution to the finished product. Sketches could also deconstruct the design to plot the stages to implementing the circuitries in configurations that evoke semiotic modes in a meaningful way. For example, matching a seashell with the sound you hear when it is held to your ear, topping a fairy's magic wand with an LED light so it appears to sparkle with magic, or imitating a billow of smoke coming from a dragon's nostrils. Some students enacted emotions through a series of movements instead. For example, when the reader touches a vase that has been forbidden and it breaks, the hair of the child embedded with e-textile stands on end to indicate his alarm.

There were also cases where students reworked pages of well-known picturebooks. B. I. chose to reinvent Shaun Tan's The Red Tree as a pop-up book embedded with light. Druker (2018) explains that Tan's collage technique and colour usage create chaotic scenes that reflect the character's anxiety and depression. The ending of the story comes as a surprise as the young girl enters her darkroom to discover a small spark of red that flourishes into a full-size flame-red tree that inspires a sense of hope. The student considered how the addition of LEDs would amplify the contrast, and the red lights add to the intensity of the red at the end of the book, giving it even a deeper impact.

The project had very few restrictions, and students were not expected to adhere to their first idea, all the more so because their experimentation with the new materials led a few to change their initial designs. While some students built their drawings around the interaction, other students who were in the habit of drawing daily used the interactions to enhance their drawings. Their learning and making of circuits differed according to their interest, background, and the story scenes that they chose to build upon. However, it can be difficult for students who are not accustomed to thinking through drawing. The workshop functioned as an icebreaker where students could share their strengths with one another while honing their artistic skills and developing an aptitude for circuitry. The worksheets and tasks encouraged students from visual arts to practice expression through writing and those from other disciplines to express themselves visually through sketches. Regardless of the students' backgrounds, the sketches they submitted showed their enthusiasm for manipulating new material to fit a narrative context and generate creative engagements for children. 


\section{Prototypes and Project Outcomes}

At the final workshop, students presented their work in class and explained how they applied theory to practice. Almost all the students saw value in employing paper circuits and interaction through LEDs to create layers of meaning as they ventured to convey literal and metaphoric implications. Nikolajeva and Scott's (2006) conceptualization of symmetric, complementary, and counter-narrative image and text The workshop functioned as an icebreaker where students could share their strengths with one another while honing their artistic skills and developing an aptitude for circuitry relationships were among the most frequently employed theoretical lens. In symmetric image and text relationships, students utilized LEDs merely to highlight the existing imagery. In complementary works, the paper circuits enriched the illustrations and text but did not alter the meaning drastically. In the counter-narratives, the most demanding of the three - this is why there were very few examples -students were to employ LEDs to further the story in ways that were unexpected and formulate metaphoric utilization of the circuit systems. The symmetric image, text, and circuit materiality were the most widely employed in the projects submitted. Some of these projects explored what the LED could represent in daily life: the flame of a candle on a birthday cake, shining eyes, or flashes of light. Many students referred to them with LEDs as natural phenomena observed in everyday life such as lightning bolts, the sun, and the stars. The stars were of particular interest to a student who aspired to introduce lessons on the celestial sphere and astrology. In this project, by pressing on the symbol for the star constellations, changes in alternate constellations would appear.

Some students chose to explore the complementary image and text relationship. One story made use of the LEDs' literal meaning as an artificial light source adoring a foldable Christmas tree that was a tribute to Dr. Seuss's story of Grinch. The image and the light were enriched by the Grinch's dawning realization that Christmas does not come from a store. She explained that the LED lights on the Christmas tree not only complement the visual narrative aesthetically but are also a tool to direct the reader to ponder the deeper message of the story. 


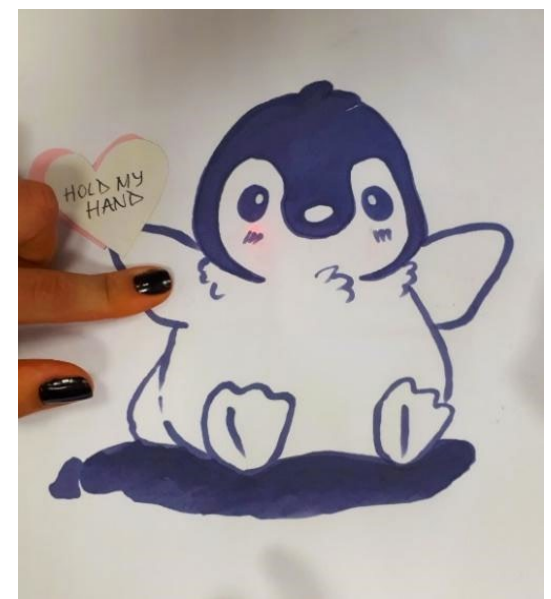

Figure 5. Hold My Hand (2019), by Feyza Beştoy

There were also projects that utilized LEDs to demonstrate emotions. As a character's capacity to express or require compassion can contribute to the young readers' empathetic engagement with animals, F. B. illustrated a baby penguin (Figure 5) who is asking the reader to hold hands, thus requesting a connection and affection. Pressing the hand of the penguin, which is the button of the circuitry, activates the red LED and the penguin's cheeks are coloured with a pink haze. In this case, the story about the penguin was enriched by the interaction as touching the character and in return seeing its immediate response might inspire feelings of conviviality. The story entitled "Pluto's Adventure" by B. İ. also sought to express empathy through a relationship connecting the planets (Figure 6). This work narrated Pluto's emotional turmoil after learning that it had been reclassified and was no longer a planet. Three different colours, yellow, blue and red, represented the sun, Earth and Pluto who were the main characters in the story. The narrator conveys Pluto's sadness and implies the demoted planet's heartbreak with the expressive quality of the red colour of the LED light. The student also added the feature of sound as the picturebook was configured as an audiobook that narrates the tale through a QR code on each page.

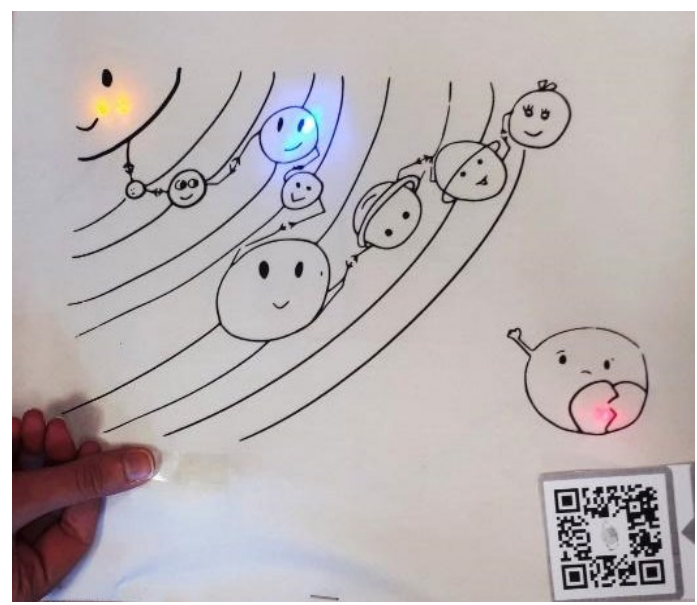

Figure 6. Pluto’s Adventure (2019), by Büşra İzgi. 
While red light in the previous example was used to express emotions, it represented enchantment in another work. N. N. decided to use LEDs as a metaphor for the magic in Cinderella's story and most particularly the enchanted dress. Nikolajeva (1996) asserts that magical artefacts in fairy tales are chronotopes, and Cinderella's iconic dress is the catalyst to her transformation from scullery maid to princess. The student chose to clothe the characters' costumes in wearable technologies and preferred to hide the circuitry lighting Cinderella's dress to "make the magic more magical". The mysteriously dreamlike quality of the illustration aimed not only to captivate children's interest in the story but also to attract children's attention to the significant moment of the tale, emphasizing the transformation.

Another student was also inclined toward fairy tales. These well-known stories provide a context and familiarity for children that our students could build on although "fairy tales pose particular challenges to illustrators, in addition to the iconic images that new artists have to negotiate or engage with when they embark on illustrating fairy tales" (Joosen, 2018, p. 477). Undaunted by this challenge, B. Ö. chose to reimagine Charles Perrault's Bluebeard. He was specifically interested in the critical moment in the fairy tale when Bluebeard warns his wife not to enter the forbidden room. The foldable page depicts Bluebeard and his wife in front of four doors: Bluebeard and his wife are in the centre; on one folded panel Bluebeard holds all the keys, and on the other panel is one key lighted with red. The illustration shows that Bluebeard hands his wife the two keys that the student designates with LEDs, one white the other red, to differentiate the significance of different keys, and therefore of different doors. Although the quotation from the tale clearly warned the character not to enter the small, locked room, the interactivity in the illustration invites just that action. The key to the prohibited room lights up with red when the wife takes it and uses it. Recalling Nikolajeva and Scott (2006) and the image and text relationship categories they suggested (p. 226), this example indicates how material engagement functions as complementary to the image-text relationship.

While some students focused on image, text, and sound, others were interested in incorporating tactility utilizing soft circuits. Campagnaro (2016) explains that Bruno Munari's I Prelibri (The Prebooks) that ask young children's co-authorship in twelve pocket-size books constructed from different materials but without images or text foster toddlers' imagination based solely on sensorial experiences. Similarly, one of the students conducted textile-based experimentation to create a responsive page. Just using a piece of cloth, conductive threads, thermochromic paint, and a programmable microcontroller such as an Arduino Uno, she set out to create a book page made from a piece of cloth that is a canvas for changes through time. The conductive 
threads woven through the cloth activate the scene as four lines gradually appear one by one that could be interpreted as branches while wisps of smoke arise from the heat. Two leaves emerge as if flying through the wind. The sequence of the emerging images was designed to culminate in a surprise at the end. The page is the picturebook, and by activating the different interactive materials, there are at least five discrete scenes from the first to the last page. The tactility invites the child reader to touch the surface, but more importantly, the wordlessness and ambiguity in imagery evoke their imagination to tell their own story. This book like Munari's supports children's co-authorship through textiles, but with the addition of e-textiles and conductive threads, this student has introduced interactivity which is not present in Munari's books.

The use of the interaction triggered by LEDs even managed to convey the difficult-to-express paradox in one project. A kitchen scene is presented where a boy opens the door to the refrigerator and encounters the warning "Do Not Press the Button" a lit red LED that represents the forbidden button. However, as soon as the reader opens the fridge, they have already activated the button on embedded circuits even before seeing the warning. C.K. experimented with the image-text-material synergy in her picturebook to prompt children to think about the interaction itself in a humorous way.

From the interaction of technology with aesthetic formulations in the final works, it is evident that the primary concerns of the students were to either provide playful reading with surprise elements or to encourage children to think about making circuits. Students reflected on both physical and narrative components in books by linking circuit systems with illustrated objects or phenomena in the story in metaphorical ways and sought ways to incorporate technology into the narrative. The final products demonstrate that the students have considered the image-textmaterial relationship as symmetrical (e.g., dots signifying star, text explaining constellations, LEDs shining like a star), complementary (e.g., the cuteness of a baby penguin asks closeness to the child, the text saying "Hold my hand!" and lights on the cheeks), or a counter-narrative (e.g., in contrast to the text, "Don't press the button", on the fridge, the reader is asked to open the fridge). For these engagements, while some students manipulated the circuits to reflect the narration, others selected a narration appropriate to the circuit. Hence, this hands-on workshop provided the setting where students could explore the reciprocal relationship of material and narrative engagements in the picturebook design process. 


\section{Conclusion}

This study reflected upon an experiment to integrate a hands-on workshop on conductive materials such as LEDs in an upper-level undergraduate/graduate course on children's literature drawing on interdisciplinary resources that make use of the aforementioned technologies. The theory component of the course instructed university students in fiction, nonfiction picturebooks, and academic resources in the field. The practical part of the course, the workshop, included presentations, demos, writing exercises, sketching and a final project that gave us insight into how together theory and practice supported students' learning and honed their creative thinking about children's literature. The assigned and suggested readings on the image-text and material relationships at the beginning of the semester provided students with a holistic perspective on the reading experience that assisted them in creating their own picturebooks. Students at times even considered how to go beyond verbal and visual narration to tell a story and facilitate children's sensory engagements during reading. Some sought alternative ways to enhance children's traditional book experiences through DIY textile-based electronics and sensors.

This workshop aligned with the studies on integrating theoretical approaches into drawing and illustration courses (Onmuş \& Veryeri Alaca, 2018; Veryeri Alaca \& Dinç, 2019). As such, the Children's Books course provided students with a more holistic, critical look at the children's literature realm that takes into account both sides of the equation. Students' reflections revealed that they combined theory and practice as they acquired the skills and mindset of a maker while they considered the role of playfulness, sharing knowledge, and conveying certain expressions (Kim \& Zimmerman, 2017). In short, participants as makers showed "deep engagement with content, experimentation, exploration, problem-solving, collaboration, and learning to learn" (Honey \& Kanter, 2013, p. 4). Our findings are also compatible with the work of Qi \& Buechley who pointed out that paper circuitry made technology easy and engaging for adults in higher education to create works suitable to their interest (2014). In addition to their own engagement, both undergraduate and graduate students considered how their picturebooks could entice child readers to join the world of making and develop a maker mindset.

In sum, the students sought to find novel ways to support children's multimodal and visual literacy, but by embedding conductive materials into the narrative, regardless of whether they were visible or not, they also introduced an additional literacy into the picture, electronics literacy. This model of teaching could be further expanded via collaboration with other stakeholders from different fields bringing depth and breadth to the contemporary children's 
literature education geared towards a diverse body of university students who are interested in pursuing careers in connection to children's literature and media.

\section{References}

Andersen, P. B., Bennedsen, J., Brandorff, S., Caspersen, M. E., \& Mosegaard, J. (2003). Teaching programming to liberal arts students: a narrative media approach. ACM SIGCSE Bulletin, 35(3), 109113.

Bareconductive. (2021, February 13). Awake: An electric paint projection mapping interactive artwork. https://bit.ly/3c8GQEv

Bromer Anne, C., \& Edison, J. I. (2007). Miniature books: 4,000 years of tiny treasures. Abrams.

Campagnaro, M. (2016). The function of play in Bruno Munari's children's books: A historical overview. Ricerche di Pedagogia e Didattica. Journal of Theories and Research in Education, 11(3), 93-105.

Ceylan, D. M. (2019). The effect of light interaction on reading experience of children's books: A case study on interactive sign language book. [MA Thesis]. Istanbul University.

Cheng, B., Kim, M., Lin, H., Fung, S., Bush, Z., \& Seo, J. H. (2012, February). Tessella: interactive origami light. In Proceedings of the Sixth International Conference on Tangible, Embedded and Embodied Interaction (pp. 317-318). Association for Computing Machinery. https://doi.org/10.1145/2148131.2148200

Cope, B., \& Kalantzis, M. (Eds.). (2000). Multiliteracies: Literacy learning and the design of social futures. Routledge.

De La Cruz, S., \& Bhatia, A. (2018, June). Paper piano: making circuits with everyday things. In Proceedings of the 17th ACM Conference on Interaction Design and Children (pp. 521-524). Association for Computing Machinery. https://doi.org/10.1145/3202185.3210768

Design Museum. (n.d.). Hussein Chalayan. https://bit.ly/3r9gx5f

Doonan, J. (1991). Satoshi Kitamura: Aesthetic dimensions. Children's Literature, 19(1), 107-137.

Dougherty, D. (2012). The maker movement. Innovations 7, 11-14.

Druker, E. (2018). Collage and montage in picturebooks. In B. Kümmerling-Meibauer (Ed.), The Routledge companion to picturebooks (pp. 49-58). Routledge.

García-González, M., \& Deszcz-Tryhubczak, J. (2020). On our com(mon) passions: Entanglements of research, teaching practices, and institutional lives. Critical Studies in Teaching and Learning, 8(1), 111125.

Honey, M., \& Kanter, D. E. (Eds.). (2013). Design, Make, Play: Growing the Next Generation of STEM Innovators. Routledge.

Jacoby, S., \& Buechley, L. (2013, June). Drawing the electric: Storytelling with conductive ink. In Proceedings of the 12th International Conference on Interaction Design and Children (pp. 265-268). Association for Computing Machinery. https://doi.org/10.1145/2485760.2485790

Joosen, V. (2018). Picturebooks as adaptations of fairy tales. In B. Kümmerling-Meibauer (Ed.), The Routledge companion to picturebooks (pp. 473-484). Routledge.

Kim, S. H., \& Zimmerman, H. T. (2017, October). Towards a stronger conceptualization of the maker mindset: A case study of an after-school program with squishy circuits. In Proceedings of the 7th Annual Conference on Creativity and Fabrication in Education (pp. 1-4). Association for Computing Machinery. https://doi.org/10.1145/3141798.3141815 
Kümmerling-Meibauer, B. (Ed.). (2011). Emergent literacy: children's books from 0 to 3. John Benjamins Publishing.

Kümmerling-Meibauer, B. (Ed.). (2018). The Routledge companion to picturebooks. Routledge.

LEDs. (2021) ACM Digital Library.

Leu-leu, M. (2017). Le Grenier. Editions du Seuil.

Mathis, J. B., Aziz, S., Crisp, T., Graff, J. M., Kesler, T., Liang, L., Carver Sekeres, D., \& Wilfong, L. (2014). Teaching children's literature in the 21st century. The Journal of Children's Literature, 40(1), 56-61.

Moorthy, P., Honauer, M., Hornecker, E., \& Mühlenberend, A. (2017, November). Hello world: A children's touch and feel books enhanced with DIY electronics. In Proceedings of the 16th International Conference on Mobile and Ubiquitous Multimedia (pp. 481-488). Association for Computing Machinery. https://doi.org/10.1145/3152832.3157811

Munari, B. (1980). I prelibri. Danese.

Nel, P., \& Paul, L. (2011). Keywords for children's literature. New York University Press.

Nikolajeva, M. (1996). Children's literature comes of age: Toward a new aesthetic.

Nikolajeva, M., \& Scott, C. (2006). How picturebooks work. Routledge.

Oram, H., \& Kitamura, S. (1982). Angry Arthur. Andersen Press.

Özkan, B. (2015). Fall: An interactive garment that mimics nature's responsive system of defoliation through an embedded electronic mechanism. In Adjunct Proceedings of the 2015 ACM International Joint Conference on Pervasive and Ubiquitous Computing and Proceedings of the 2015 ACM International Symposium on Wearable Computers (pp. 617-621). Association for Computing Machinery. https://doi.org/10.1145/2800835.2801675

Painter, C., Martin, J., \& Unsworth, L. (2013). Reading visual narratives: Image analysis of children's picture books. Equinox Publishing Ltd.

Panjwani, A. (2017). Constructing meaning: Designing powerful story-making explorations for children to express with tangible computational media. In Proceedings of the 17th International Conference on Interaction Design and Children (pp. 358-364). Association for Computing Machinery. https://doi.org/10.1145/3078072.3079723

Qi, J., \& Buechley, L. (2010). Electronic popables: Exploring paper-based computing through an interactive pop-up book. In Proceedings of the fourth international conference on Tangible, embedded, and embodied interaction (pp. 121-128). Association for Computing Machinery. https://doi.org/10.1145/1709886.1709909

Qi, J., \& Buechley, L. (2014, April). Sketching in circuits: designing and building electronics on paper. In Proceedings of the SIGCHI conference on human factors in computing systems (pp. 1713-1722). Association for Computing Machinery. https://doi.org/10.1145/2556288.2557391

Qi, J. and Paradiso, J. (2015). Crafting technology with circuit stickers. In Proceedings of the 14th International Conference on Interaction Design and Children (pp. 438-441). Association for Computing Machinery. https://doi.org/10.1145/2771839.2771873

Rust, C., Mottram, J. \& Till, J. (2007). Review of practice-led research in art, design \& architecture. UK, Arts and Humanities Research Council. http://shura.shu.ac.uk/7596/

Salisbury, M. (2004). Illustrating children's books: Creating pictures for publication. A \& C Black Publishers.

Salisbury, M., \& Styles, M. (2012). Children's picturebooks: The art of visual storytelling, Laurance King Publishing.

Seuss, Dr. (2016). How the Grinch stole Christmas! Harper Collins 
Shorter, M., Rogers, J., \& McGhee, J. (2014, June). Enhancing everyday paper interactions with paper circuits. In Proceedings of the 2014 Conference on Designing Interactive Systems (pp. 39-42). Association for Computing Machinery.

Stankiewicz, M. A. (2003). Between technology and literacy. International Journal of Art \& Design Education, 22(3), 316-324.

Subero, J. (2013, May 22). The Very Hungry Caterpillar interactive book, [Youtube Channel]. https://www.youtube.com/watch?v=g2OH26tDLrU

Svanaes, D. (2014). Philosophy of Interaction. In M. Soegaard \& R. Friis Dam (Eds.), The Encyclopedia of Human-Computer Interaction (2nd ed.). The Interaction Design Foundation.

Tan, S. (2001). The red tree. Lothian Books.

Timpany, C., \& Vanderschantz, N. (2012). A categorisation structure for interactive children's books: Levels of interactivity in children's printed books. International Journal of the Book, 9(4), 97-109.

Tsujii, T., Koizumi, N., \& Naemura, T. (2014, October). Inkantatory paper: Dynamically color-changing prints with multiple functional inks. In Proceedings of the adjunct publication of the 27th annual ACM symposium on User interface software and technology (pp. 39-40). Association for Computing Machinery. https://doi.org/10.1145/2658779.2659103

Tullet, H. (2013). The game of shadows (die cut board book). Phaidon.

Veryeri Alaca, I. (2019). Materiality in Picturebooks: An Introduction. Libri et Liberi, 8(2), 243-255. https://doi.org/10.21066/carcl.libri.8.2.8

Veryeri Alaca, I., \& Dinç, B. G. (2019). Tracing the Genealogical Self: Entanglements of drawing with Tim Ingold's Lines. Drawing: Research, Theory, Practice, 4(2), 271-283.

Veryeri Alaca, I., \& Onmuş, i. (2018). Integrating theory into illustration education: An interdisciplinary approach enhanced by artistic research in Istanbul. Journal of Illustration, 5(2), 247-263.

\section{How to cite this paper:}

Dinç, B. G., Özkan, B., \& Veryeri Alaca, I., (2021). Interactive Storytelling through LEDs and Paper Circuits: Tapping into Materials and Technology in Children's Literature Education. Journal of Literary Education, (4), 266-288. https://doi.org/10.7203/JLE.4.21021 